Paedagogia Christiana

I/29 (2012) - ISSN 1505-6872

\author{
Jarostaw Horowski* \\ Toruń
}

\title{
Sprawności czy kompetencje moralne?
}

Pytanie o moralność jest jednym z najważniejszych pytań, stawianych przez człowieka, niezależnie od czasu, w jakim przyszło mu funkcjonować. Moralność przekłada się bowiem nie tylko na realne skutki w życiu innych ludzi oraz w świecie materialnym, ale powoduje także zmiany w samym działającym podmiocie, który przeżywa je jako szczęście lub rozczarowanie. Fakt, że człowiek jest istotą dynamiczną, rozwijającą się w trakcie swojego życia, sprawia, że pytanie o moralność osadzane jest w kontekście pedagogicznym, przybierając postać pytania o rozwój moralny oraz o możliwości zewnętrznego wspomagania owego rozwoju. O ile postawione powyżej pytania są ponadczasowe, to kontekst społeczno-kulturowy, w jakim rozważa się je, modyfikuje zakresy, wprowadza nowe zmienne, uwrażliwia na kolejne kwestie, które brane są pod uwagę przy udzielaniu odpowiedzi. Klasyczna filozofia moralna w odpowiedzi na pytanie o moralność wskazywała, że w przypadku konkretnego człowieka wynika ona ze sprawności moralnych, jakie zostały w nim ukształtowane: jeżeli są to sprawności skłaniające ku dobru, nazywane cnotami, to po takim człowieku możemy spodziewać się pozytywnych pod względem moralnym działań; jeżeli zaś owe sprawności przybierają postać wad, jego działania mogą stanowić zagrożenie dla dobra danej osoby oraz innych ludzi. Koncepcja cnót przekładała się w pedagogice na kwestię rozwoju człowieka w kierunku coraz większej doskonałości moralnej. We współczesnych dyskusjach na temat moralności kategoria cnoty

* Dr Jarosław Horowski jest adiunktem w Katedrze Teorii Opieki i Wychowania, Pracownia Pedagogiki Filozoficznej i Chrześcijańskiej, na Wydziale Nauk Pedagogicznych UMK w Toruniu. 
została zmarginalizowana ${ }^{1}$, a w centrum uwagi znalazła się kategoria kompetencji moralnych. Analizując ją, nietrudno zauważyć, że kategoria kompetencji zbudowana jest na innych założeniach filozoficznych, odwołuje się do innej niż teoria cnót moralnych koncepcji człowieka, jego poznania i jego działania, także moralnego. Dla refleksji w dziedzinie wychowania moralnego ważne jest zatem porównanie obydwu kategorii oraz fundamentów, na jakich są zbudowane, aby w konsekwencji odpowiedzieć na pytanie, czy sprawności moralne w wychowaniu można zastąpić kompetencjami. Przyjrzyjmy się temu problemowi, wychodząc od charakterystyki przywołanych kategorii.

\section{Kategoria sprawności moralnych i jej filozoficzne fundamenty}

Odwołanie się do kategorii sprawności moralnych domaga się na początku doprecyzowania, jaka koncepcja sprawności będzie przywoływana. Próby ujęcia całości działania ludzkiego i kierujących nim zasad moralnych w ramy systematyki doprowadziły bowiem na przestrzeni wieków do sformułowania różnych teorii sprawności moralnych. Refleksję nad cnotami moralnymi - bo tak nazywane są sprawności pozytywne - podejmowali między innymi sofiści, Sokrates, Platon, Arystoteles, stoicy, Tomasz z Akwinu czy Duns Szkot ${ }^{2}$. Również współcześnie aretologia jest twórczo rozwijana ${ }^{3}$. Ani ograniczona objętość niniejszej refleksji nie pozwala na głębszą analizę różnych teorii cnoty, ani potrzeby podejmowanego tematu tego nie wymagają. Zatrzymajmy się więc jedynie nad koncepcjami Arystotelesa, Tomasza z Akwinu oraz Jacka Woronieckiego, tworzącego głównie w dwudziestoleciu międzywojennym polskiego neotomisty, etyka i pedagoga.

Mówiąc o cnocie, Arystoteles odnosi się do analiz ludzkiego czynu oraz do refleksji nad jego celem, czyli dobrem ${ }^{4}$. Zainteresowanie Filozofa skupia się przy tym na specyficznym dobru - pyta bowiem o dobro najwyższe,

1 Zob. A. Szudra-Barszcz, Czy cnoty można nauczyć?, „Ethos” 4 (2010), s. 108.

2 Zob. R. Cyrklaff, J. Wichrowicz, Aretologia, w: F. Gryglewicz, R. Łukaszyk, Z. Sułowski (red.), Encyklopedia katolicka, t. I, Lublin 1995, kol. 903-904.

3 Zob. np. A. MacIntyre, Dziedzictwo cnoty. Studium z teorii moralności, Warszawa 1996; J. Woroniecki, Katolicka etyka wychowawcza, t. I, II/1, II/2, Lublin 2000; M. Mróz, Człowiek w dynamizmie cnoty. Aktualność aretologii św. Tomasza z Akwinu w świetle pytania o podstawy moralności chrześcijańskiej, Toruń 2001; tenże, Tajemnica ludzkiej nieprawości. Aktualność nauki św. Tomasza z Akwinu o złu moralnym i wadach głównych, Toruń 2010; M. Gogacz, Osoba zadaniem pedagogiki. Wykłady bydgoskie, Warszawa 1997.

4 Zob. Arystoteles, Etyka nikomachejska, w: tenże, Dzieła wszystkie, t. 5, Warszawa 1996, 1094a. 
które stanowi dla człowieka cel ostateczny5. Owo pytanie znajduje połowiczne rozstrzygnięcie. Wskazaniu, że poszukiwanym dobrem jest szczęście, a „być szczęśliwym to to samo, co dobrze żyć i dobrze się mieć”, towarzyszy bowiem konstatacja, że wchodząc w szczegóły istoty szczęścia napotkamy na rozbieżne stanowiska: jedni widzą je w rozkoszy, inni w dzielności obywatelskiej, jeszcze inni w teoretycznej kontemplacji ${ }^{6}$. Dalsza refleksja prowadzi jednak Arystotelesa do następującego wniosku:

Otóż - jeśli swoistą funkcją człowieka jest działanie duszy zgodne z rozumem lub nie bez rozumu; i jeśli swoista funkcja człowieka i człowieka etycznie wysoko stojącego jest identyczna co do swego rodzaju, tak jak funkcja cytrzysty i cytrzysty wybitnego, i tak w ogóle we wszystkich przypadkach, ponieważ do funkcji w ogóle przyłącza się tylko ów wyższy stopień spowodowany dzielno-

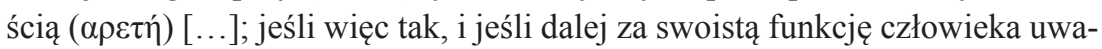
żamy pewien rodzaj życia, a mianowicie działanie duszy i postępowanie zgodne z rozumem, za swoistą zaś funkcję człowieka dzielnego to samo działanie wykonywane w sposób szczególnie dobry [...] najwyższym dobrem człowieka jest działanie duszy zgodne z wymogami tej dzielności, o ile zaś istnieje więcej rodzajów tej dzielności, to zgodnie z wymogami najlepszego i najwyższego jej rodzaju?

Innymi słowy, Arystoteles wyraża przekonanie, że szczęściem człowieka jest postępowanie zgodne z tym, co nakazuje cnota, czyli niepopełnianie niczego haniebnego lub niegodziwego, czynienie w każdych warunkach tego, co jest najlepsze ${ }^{8}$.

Odnosząc się do dzielności, Arystoteles stwierdza: „Dwa tedy są rodzaje dzielności, z których jedne stanowią zalety dianoetyczne, drugi zaś - zalety etyczne, czyli cnoty", przy czym zalety dianoetyczne łączy z rozumem (są to cnoty intelektualne nieprzekładające się bezpośrednio na czyn), natomiast etyczne z częścią duszy uczestniczącą poniekąd w rozumie (wolą) oraz nierozumną częścią duszy (zdolną do żywienia pragnień) - cnoty etyczne znajdują wyraz w czynie. Dzielność etyczna polegałaby zatem na tym, aby działać zawsze zgodnie z rozumem: „dzielność etyczna jest trwałą dyspozycją do pewnego rodzaju postanowień, polegającą na zachowywaniu właściwej ze względu na nas średniej miary, którą określa rozum, i to w sposób, w jaki by

\footnotetext{
5 Zob. tamże.

6 Zob. tamże, 1095a-1096a.

7 Tamże, 1098a.

8 Zob. tamże, 1101a.

9 Tamże, 1103a.
} 
ją określił człowiek rozsądny"10. Ze słów Arystotelesa można wywnioskować jego przekonanie co do tego, że czymś innym jest wiedza na temat działania dobrego, a czymś innym samo działanie. Konsekwentnie Arystoteles stwierdza, że dzielność etyczna rozwija się inaczej niż zalety dianoetyczne: „Owóż zarówno powstanie, jak i rozwój zalet dianoetycznych jest przeważnie owocem nauki i dlatego wymagają one doświadczenia i czasu; etycznych natomiast nabywa się dzięki przyzwyczajeniu, skutkiem czego nazwa ich $[\ldots]$ nieznacznie tylko odbiega od wyrazu «przyzwyczajenia»" ${ }^{11}$. W dalszym wywodzie doprecyzowuje:

cnót [...] nabywamy dzięki uprzedniemu wykonywaniu czynów [etycznie dodatnich], jak się to dzieje także i w dziedzinie innych sztuk. Tych bowiem rzeczy, których trzeba się nauczyć, by je wykonywać, tych uczymy się właśnie przez ich wykonywanie; tak np. budowniczowie kształcą się budując domy, a cytrzyści - grając na cytrze. Tak samo stajemy się sprawiedliwi postępując sprawiedliwie, umiarkowani przez postępowanie umiarkowane, mężni przez mężne zachowywanie się․

Myśl filozoficzna Arystotelesa została podjęta przez Tomasza z Akwinu. Istotne dla kwestii wychowania moralnego tezy zawarł on w dwóch traktatach Sumy teologicznej, poświęconych szczęściu oraz sprawnościom. Część poświęcona szczęściu rozpoczyna się od analizy ludzkiego działania, a konkretniej jego celu oraz tego, w jaki sposób wpływa on na ludzkie działanie: „Naprzód wysuwa się sprawa ostatecznego celu życia ludzkiego, a następnie tych rzeczy, które albo do celu prowadzą, albo od niego odwracają. Cel bowiem stanowi o środkach, służących do jego osiągnięcia. Ponieważ zaś szczęście uchodzi za ostateczny cel życia ludzkiego, należy wpierw rozważyć ostateczny cel w ogólności, a następnie szczęście"13. Akwinata zadaje również pytanie, czy wszyscy ludzie posiadają jeden cel ostateczny, na które udziela następującej odpowiedzi: „gdy chodzi o to, co jest istotne w celu, wszyscy się zgadzają w pożądaniu celu ostatecznego, gdyż wszyscy pragną osiągnąć swą doskonałość, która stanowi istotę tegoż celu. Nie wszyscy jednak są zgodni co do tego, w czym ów cel ostateczny znajduje się. Niektórzy bowiem pożądają bogactw jako dobra ostatecznego, inni rozkoszy, a inni jeszcze innych rzeczy"14.

\footnotetext{
10 Tamże, 1107a.

11 Tamże, 1103a.

12 Tamże, 1103a-1103b.

13 Tomasz z Akwinu, Suma teologiczna, t. 9: O szczęściu, Londyn 1963, 1-2, q. 1.

14 Tamże, 1-2, q. 1, a. 8.
} 
Refleksja nad człowiekiem, którą podejmuje Tomasz z Akwinu, mimo że $\mathrm{w}$ wielu miejscach zbieżna $\mathrm{z}$ ustaleniami Arystotelesa, prowadzi go jednak do innych wniosków. Zgadza się z Arystotelesem w tym, że szczęście nie polega ani na bogactwach, ani na czci, ani na sławie, ani na władzy, ani na dobru ciała, ani na rozkoszy ${ }^{15}$. Tomasz nie utożsamia jednak szczęścia z jakimś dobrem duszy - czyli z cnotą ${ }^{16}$. Eliminacja poszczególnych dóbr prowadzi go do następującego wniosku:

Szczęście [...] jest dobrem doskonałym, całkowicie zaspokajającym pożądanie. Nie byłoby bowiem celem ostatecznym, jeśliby po jego osiągnięciu zostało jeszcze coś do pożądania. Przedmiotem zaś woli, czyli pożądania ludzkiego, jest dobro powszechne, podobnie jak przedmiotem umysłu jest prawda powszechna. Jasne więc, że nic nie może zaspokoić woli człowieka poza dobrem powszechnym, które nie znajduje się w dobru stworzonym, ale tylko w Bogu, gdyż każde stworzenie posiada tylko cząstkową dobroći ${ }^{17}$.

Abstrahując od tego, w czym Tomasz widzi cel ostateczny, należy zwrócić uwagę na jego przekonanie co do związku między dobrem, które jest celem ostatecznym człowieka, a jakością jego działań. Dobro, w jakim upodobała sobie wola, przekłada się, jego zdaniem, na konkretne czyny, będące środkami do celu ostatecznego. Wychodząc od tych ustaleń, można powiedzieć, że ktoś, kto upatruje szczęścia w rozkoszy, będzie szukał możliwości jej zrealizowania, nawet jeżeli będą stały z tym w sprzeczności normy, jakie zostały ustalone w życiu społecznym. Myśląc o wychowaniu moralnym, należałoby zatem najpierw zadać pytanie, co jest celem ostatecznym konkretnego człowieka i w jaki sposób dąży on do owego celu. Dochodzimy w ten sposób do pojęcia sprawności, która dla Tomasza z Akwinu: „to dyspozycja, dzięki której ktoś lub coś jest dobrze lub źle przysposobiony w stosunku do siebie lub w stosunku do innego bytu"18. Omawiając, na czym to przysposobienie polega i jak przekłada się na kwestie wychowawcze, odwołajmy się jednak do rozważań Jacka Woronieckiego, który w XX wieku rozwijał myśl Arystotelesa i Tomasza z Akwinu w dziedzinie pedagogiki.

W koncepcji Jacka Woronieckiego ludzkie działanie jest również uwarunkowane dążeniem do szczęścia. Owo szczęście może być osiągnięte, zda-

${ }^{15}$ Zob. tamże, 1-2, q. 2, a. 1-6.

16 Zob. tamże, 1-2, q. 2, a. 7.

17 Tamże, 1-2, q. 2, a. 8.

18 Tomasz z Akwinu, Suma teologiczna, t. 11: O sprawnościach, Londyn 1965, 1-2, q. 49 , a. 1. 
niem Dominikanina, w zjednoczeniu z Bogiem ${ }^{19}$. Na tej drodze człowiek staje przed różnego rodzaju zadaniami, które wynikają z codziennego życia. Droga do zjednoczenia z Bogiem okazuje się więc drogą realizacji różnych dóbr doczesnych ${ }^{20}$. Zdaniem Woronieckiego, tworzącego przede wszystkim w okresie międzywojennym, problemem ówczesnego człowieka nie była identyfikacja dobra, które może dać mu szczęście, ale umiejętność sprostania wyzwaniom moralnym, jakie pojawiają się przed nim na co dzień. Diagnoza, jaką Woroniecki formułuje w wyniku obserwacji współczesnych mu ludzi, wskazuje na trudności w realizacji tego, co rozum określa jako dobro. Problem widzi Woroniecki przede wszystkim w słabej woli.

Konsekwencją powyższej diagnozy jest koncepcja wychowania, w której centralnym zagadnieniem stają się sprawności moralne ${ }^{21}$. Woroniecki uważał, że przełożenie wiedzy o dobru na dobry czyn wiąże się z rozwojem cnót, a szczególnie roztropności doskonalącej rozum ${ }^{22}$, sprawiedliwości doskonalącej wolę ${ }^{23}$ oraz umiarkowania i męstwa, które są doskonałościami władz zmysłowych - odpowiednio pożądliwej i popędliwej. Wymienione tutaj doskonałości władz człowieka nie są przez Woronieckiego rozumiane jako formy nawyków, prowadzące do schematycznych działań ${ }^{24}$. Roztropność jest bowiem rozumiana jako umiejętność rozumnego określenia, co w danej sytuacji należy czynić, aby osiągnąć szczęście ${ }^{25}$, sprawiedliwość jako zdolność wierności decyzji rozumu ${ }^{26}$, umiarkowanie jako umiejętność rezygnacji z dóbr osobistych, jeżeli tego wymaga dobro wskazane przez rozum, natomiast męstwo jako wytrwałość w realizacji dóbr trudnych, szczególnie gdy określone działanie łączy się z lękiem²7.

19 Zob. J. Woroniecki, Katolicka, t. I, s. 69-70, 80.

${ }^{20}$ Zob. tamże, s. 90; tenże, Roztropność - cnota dobrze wychowanego sumienia, „Przewodnik Katolicki” 37 (1964), s. 334.

${ }^{21}$ Zob. tenże, Program integralnej pedagogiki katolickiej, „Ateneum Kapłańskie” 47 (1947), s.166-167; tenże, Metoda i program nauczania teologii moralnej, Lublin 1922, s. 72; tenże, Nawyk czy sprawność. Centralne zagadnienie pedagogiki katolickiej, Wilno 1939, s. 3.

${ }^{22}$ Zob. tenże, Roztropność, s. 333-334; tenże, Studium nad kardynalną cnota roztropności, „Kwartalnik Teologiczny Wileński” 1-2 (1923-1924), s. 230; tenże, Katolicka, t. I, s. 340.

${ }^{23}$ Zob. tenże, Wychowanie społeczne i praca społeczna, „Prąd” 1-2 (1921), s. 17; tenże, Sprawiedliwość. Najważniejsza jej postać: sprawiedliwość współdzielcza, w: tenże, Wychowanie człowieka. Pisma wybrane, Kraków 1961, s. 155, 166.

${ }^{24}$ Zob. tenże, Nawyk, s. 6-8.

${ }^{25}$ Zob. tenże, Studium, s. 227.

${ }^{26}$ Zob. tenże, Umiejętność rządzenia i rozkazywania, Lublin 2001, s. 55-57.

${ }^{27}$ Tenże, Cnota kardynalna mestwa. Jej istotne cechy, niedomagania i wychowanie, „Szkoła Chrystusowa” 4 (1938), s. 233-237; tenże, Cnota kardynalna umiarkowania, „Szkoła Chrystusowa" 5 (1930), s. 228. 
Najtrudniejsze pytanie, związane z cnotami moralnymi, pojawia się w kontekście myśli wychowawczej i dotyczy możliwości wspierania rozwoju cnót w procesie wychowania. Nieprzypadkowo używam tutaj zwrotu «wspieranie rozwoju». Jacek Woroniecki był przekonany, że podstawowym podmiotem wychowania jest sam wychowanek ${ }^{28}$ i tylko on - dzięki własnym działaniom - może doskonalić poszczególne swoje władze. Dominikanin uważał, że cnoty (podobnie jak i wady) rozwijają się w czynie ${ }^{29}$. Zdolny do wielkich czynów będzie tylko ten człowiek, który w swoim życiu stawiał czoła wyzwaniom, jakie przed nim się pojawiały, a nie ten, który za każdym razem uciekał przed trudnościami ${ }^{30}$. Tylko czyn przynosi bowiem wartościową wiedzę o rzeczywistości, tylko czyn - za sprawą zadowolenia lub rozczarowania, jakie po nim następuje - daje trafne wskazanie dobra i zła, tylko czyn prowadzi do integracji uczuć z działaniami władz umysłowych (nazywanej sublimacją) ${ }^{31}$. Co zatem należy czynić, aby dojrzewający człowiek podjął czyn? Woroniecki odpowiada, że dojrzewającemu człowiekowi należy dać ,stałe umiłowanie jakiegoś wielkiego dobra, które by go silnie pociągało i zmuszało przez to do bardzo starannego zabiegania o to wszystko, co jest koniecznym do osiągnięcia go"32. Ważną rolę w tym procesie Woroniecki przypisywał życiu społecznemu, które może albo motywować rozwijającego się człowieka do działań na rzecz dobra, przyczyniających się do rozwoju cnót, albo może nie pobudzać go do rozwoju, pozwalając mu ulegać jedynie dobrom zmysłowym i tym samym przyzwalać na rozwój wad $^{33}$. Z kolei wartość oddziaływań wychowawcy Woroniecki uzależniał od wartości oddziaływań społecznych ${ }^{34}$.

${ }^{28}$ Zob. tenże, Program, s. 174; tenże, Nawyk, s. 22; tenże, Dlugomyślność jako cnota właściwa wychowawcy, „Szkoła Chrystusowa” 4 (1930), s.189.

${ }_{29}$ Zob. tenże, Rozwój osobistości człowieka, w: tenże, Wychowanie człowieka, s. 75-77; tenże, Nawyk, s. 18, 26-28; tenże, Metoda, s. 26.

${ }^{30}$ Zob. tenże, Cnota kardynalna męstwa, s. 236-237; tenże, Wady moralne i stopnie ich nasilenia, „Szkoła Chrystusowa” 11 (1938), s. 243-244.

31 Zob. tenże, Katolicka, t. II/1, s. 33-34.

32 Tenże, Studium, s. 242; zob. tenże, Analiza mitości i jej stopnie, w: Przyjaźń chrześcijańska. Zbiór studiów, Kielce 1948, s. 84-85.

${ }^{33}$ Zob. tenże, Nacjonalizm a katolicyzm, w: Nacjonalizm a katolicyzm. Opinie biskupów, uczonych, polityków i publicystów współczesnych, Poznań 1927, s. 105; tenże, Program, s. 273.

${ }^{34}$ Zob. tenże, Cnota kardynalna umiarkowania, s. 234-236; tenże, Program, s. 273-274 . 


\section{Kategoria kompetencji moralnych i jej filozoficzne fundamenty}

Termin «kompetencje» posiada ugruntowaną już pozycję we współczesnych dyskusjach edukacyjnych, tym bardziej, że pojawia się zarówno w europejskich $^{35}$, jak i krajowych ${ }^{36}$ dokumentach, opisujących pożądane efekty kształcenia. Nabiera przy tym różnych sensów w zależności od kontekstu, w jakim jest stosowany. Jeżeli pozostawimy na boku rozumienie kompetencji jako formalnych uprawnień ${ }^{37}$, to termin ten kojarzyć się będzie przede wszystkim z fachowością w odniesieniu do określonej aktywności, szczególnie w sferze gospodarczo-ekonomicznej ${ }^{38}$. We współczesnych dyskusjach edukacyjnych termin «kompetencje» doprecyzowuje się jednak także jako kompetencje społeczne, rozumiejąc je jako «dojrzałość społeczną», «uspołecznienie», «umiejętność znalezienia się odpowiednio w sytuacji» ${ }^{39}$. Jednym z aspektów kompetencji społecznych są kompetencje moralne. Robert Kwaśnica wyjaśnia, czym one są, w następujących słowach:

Kompetencje moralne nie są - mimo pozorów - tym samym, co wiedza o normach i nakazach moralnych, są natomiast zdolnością prowadzenia refleksji moralnej. Ich udział w naszym życiu wyraża się w pytaniach o prawomocność moralną naszego postępowania. W zależności od poziomu rozwoju moralnego pytania te zadajemy inaczej, różnie też na nie odpowiadamy, ale domagają się one wciąż tego samego - namysłu nad moralną prawomocnością naszych za-

35 Zob. Zalecenie Parlamentu Europejskiego i Rady dnia 18 grudnia 2006 r. w sprawie kompetencji kluczowych w procesie uczenia się przez całe życie (2006/962/WE), „Dziennik Urzędowy Unii Europejskiej” L 394 z dnia 30.12.2006, s. 10-18; Zalecenie Parlamentu Europejskiego i Rady dnia 23 kwietnia 2008 r. w sprawie ustanowienia europejskich ram kwalifikacji dla uczenia się przez całe życie (2008/C 111/01), „Dziennik Urzędowy Unii Europejskiej” C $111 \mathrm{z}$ dnia 6.05.2008, s. 1-7.

${ }^{36}$ Zob. Rozporzadzenie Ministra Nauki i Szkolnictwa Wyższego z dnia 4 listopada 2011 r. w sprawie wzorcowych efektów kształcenia, Dz.U. z $2011 \mathrm{nr} 253$ poz. 1521; Rozporządzenie Ministra Nauki i Szkolnictwa Wyższego z dnia 17 stycznia 2012 r. w sprawie standardów ksztatcenia przygotowującego do wykonywania zawodu nauczyciela, Dz.U. z 2012 nr 0 poz. 131.

37 Zob. E. Sobol, Słownik wyrazów obcych, Warszawa 1995, s. 575.

${ }^{38}$ Zob. M. Nussbaum, Ksztatcenie dla zysku, kształcenie dla wolności, w: B. D. Gołębniak (red.), Pytanie o szkołę wyższa w trosce o człowieczeństwo, Wrocław 2008, s. 66; T. Szkudlarek, Ekonomia i etyka: przemieszczenia dyskursu edukacyjnego, w: B. D. Gołębniak (red.), dz. cyt., s. 28; zob. E. Potulicka, J. Rutkowiak, Neoliberalne uwiktania edukacji, Kraków 2010.

39 Zob. S. Sławiński i in. (red.), Słownik kluczowych pojęć związanych z krajowym systemem kwalifikacji, Warszawa 2011, s. 36-38. 
chowań. A zatem refleksja, którą umożliwiają kompetencje moralne, jest zawsze autorefleksją, jest samorozumieniem wzbudzanym i podtrzymywanym wciąż przez to samo pytanie: jaki powinienem być i w jaki sposób powinienem postępować, by z jednej strony dochować wierności sobie i nie ulec duchowemu zniewoleniu, a z drugiej - by swoim postępowaniem nie ograniczać innych ludzi w ich prawach do wewnętrznej wolności i podmiotowości i w prawie do wyboru własnej drogi? $?^{40}$

Zwrócenie uwagi na konieczność kształtowania kompetencji społecznych czy kompetencji moralnych w ramach procesów edukacyjnych można tłumaczyć kilkoma względami. Przede wszystkim wynika ona z faktu, że uczestnictwo w życiu społecznym, którego częścią jest praca zawodowa, stawia wobec różnego rodzaju dylematów moralnych, domagających się rozstrzygnięcia, a nieopisanych przez regulujące aktywność zawodową procedury. Kształtowanie kompetencji moralnych ma jednak służyć także innym celom. Ponieważ w sferze gospodarczo-ekonomicznej funkcjonuje przede wszystkim kryterium zysku, dlatego wytwarza ona struktury dehumanizujące człowieka, czyniące z niego nie podmiot, który realizuje się poprzez pracę, ale „siłę roboczą”. Myśl o kompetencjach społecznych i moralnych jako efekcie kształcenia łączy się więc z nadzieją, że edukacja przyczyniać się będzie nie tyle do adaptacji jednostki w zastanych uwarunkowaniach społecznych, gospodarczo-ekonomicznych czy kulturowych, ale do jej emancypacji z owych struktur, czyli że edukacja będzie upodmiatawiać jednostkę ${ }^{41}$.

Ważne niewątpliwie cele, które towarzyszą dyskursowi o kompetencjach moralnych, sprawiają, że niejako poza margines zainteresowań przesunięte zostaje pytanie o to, jak kompetencje moralne przekładają się faktycznie na moralne postępowanie. Czy przypadkiem dyskursowi temu nie towarzyszy przyjęte a priori założenie, że namysł „,nad moralną prawomocnością naszych zachowań" będzie prowadził do moralnych zachowań? Czy zwolennicy tej koncepcji są w stanie wytłumaczyć zachowanie, którego podmiot wie, gdzie leży dobro, a jednak wybiera zupełnie inne rozwiązanie? Czy nie jest to przypadkiem nowa wersja sformułowanego wyraźnie przez Sokratesa intelektualizmu moralnego? Poszukajmy odpowiedzi na te pytania poprzez analizę teorii sumienia, zbudowanej w oparciu o teorię działania komunikacyjnego Jürgena Habermasa. Stanowi ona niewątpliwie punkt odniesienia

${ }^{40}$ R. Kwaśnica, Wprowadzenie do myślenia o nauczycielu, w: Z. Kwieciński, B. Śliwerski (red.), Pedagogika. Podręcznik akademicki, t. 2, Warszawa 2004, s. 300.

${ }^{41}$ Zob. A. Męczkowska, Kompetencja, w: T. Pilch (red.), Encyklopedia pedagogiczna XXI wieku, t. II, Warszawa 2003, s. 693-695. 
dla zwolenników sprowadzenia rozwoju moralnego do rozwoju kompetencji moralnych.

Jeden z najczęściej cytowanych współczesnych filozofów ${ }^{42}$, także na terenie etyki i pedagogiki, którym jest niewątpliwie Jürgen Habermas, nie zajmuje się de facto teorią etyczną ani nie konstruuje teorii sumienia ${ }^{43}$. Jego zainteresowania skupiają się na ,strukturach działania ukierunkowanego na dochodzenie do porozumienia", co ma służyć budowaniu teorii społecznej ${ }^{44}$. Poszukiwania prowadzone przez Habermasa sytuują się zatem - zgodnie z deklaracją Autora - w obszarze socjologii. Rozważając wspomniane kwestie, Habermas nie jest jednak w stanie uniknąć pytań o człowieka, jego poznanie, budowanie sądów moralnych czy o rozwój moralny. Odpowiedzi na nie stają się z kolei fundamentem teorii etycznej i pedagogicznej. Przyjrzyjmy się zatem, jak Habermas pojmuje sumienie i jego rozwój. Ta druga kwestia jest dużo bardziej interesująca, ponieważ sama koncepcja sumienia zostaje przez Habermasa przejęta z tradycji Oświecenia - jest to koncepcja racjonalistyczna, która sumienie rozumie jako władzę poznawczą, formułującą normy etyczne ${ }^{45}$. Oczywiście nie jest to bezkrytyczne przejęcie myśli oświeceniowej, która pod wpływem pozytywizmu ograniczyła działalność rozumu do funkcji instrumentalnych. Habermas proponuje zróżnicowanie świata zewnętrznego na świat obiektywny i świat społeczny ${ }^{46}$, aby odejść od instrumentalnego sposobu myślenia o świecie ${ }^{47}$. Zwrócenie uwagi na świat społeczny łączy się ze wskazaniem na jego specyfikę. Świat społeczny domaga się racjonalizacji, jednak - aby ją osiągnąć - rozum powinien pełnić funkcje znaczeniotwórcze, wartościujące i emancypacyjne. Owo dopowiedzenie nie zmienia jednak samej koncepcji sumienia, które - jak zaznaczyłem powyżej - łączone jest przede wszystkim z rozumem ${ }^{48}$.

Racjonalizacja świata społecznego nie mogłaby się dokonać, gdyby poszczególne jednostki ludzkie nie modyfikowały swojej świadomości moralnej. Modyfikacja, o której mowa, dokonuje się w świecie intersubiektyw-

42 Zob. A. M. Kaniowski, Rehabilitacja i transformacja filozofii praktycznej, w: J. Habermas, Teoria działania komunikacyjnego, t. 1, Warszawa 1999, s. IX.

${ }^{43}$ Zob. J. Górnicka-Kalinowska, Idea sumienia w filozofii moralnej, Warszawa 1999, s. 116.

${ }^{44}$ J. Habermas, Teoria, t. 1, s. 8.

${ }^{45}$ Zob. R. Spaemann, Szczęście a życzliwość. Esej o etyce, Lublin 1997, s. 177.

46 Zob. J. Habermas, Teoria, t. 1, s. 462.

${ }^{47}$ Zob. J. Górnicka-Kalinowska, dz. cyt., s. 116-119; A. Szahaj, Teoria krytyczna szkoły frankfurckiej, Warszawa 2008, s. 67-87.

48 Świadczą o tym słowa Habermasa: ,ja sam skłaniam się [...] ku stanowisku kognitywistycznemu, zgodnie z którym kwestie praktyczne mogą zasadniczo być rozstrzygane w trybie argumentacji”. J. Habermas, Teoria, t. 1, s. 49. 
nych konstrukcji językowych, pojawiających się w przestrzeni komunikacji. Habermas zwraca uwagę, że używając języka uczestnicy komunikacji „wysuwają normatywne roszczenia ważnościowe i odnoszą się do czegoś we wspólnym im świecie społecznym"49 (nazywane jest to funkcją regulatywną języka). To właśnie dzięki nim podmiot może poddać krytyce tradycję, religię czy konwencje, kreując tym samym nowe wartości, organizując społeczne cele czy służąc emancypacji z przesądów ${ }^{50}$. Modyfikacja świadomości moralnej jest niczym innym, jak procesem rozwoju sumienia, o który w niniejszej refleksji chodzi.

Habermas stara się również zrozumieć, w jaki sposób podmiot dojrzewa w wymiarze moralnym ${ }^{51}$. Odwołuje się w tej kwestii do myśli Jeana Piageta i Lawrence'a Kohlberga, którzy - podobnie jak on - rozwój moralności łączą z aktywną zmianą we wzorach myślenia, wywołaną przez doświadczane sytuacje rozwiązywania problemów ${ }^{52}$. Teoria Kohlberga stwierdza następowanie po sobie w świadomości indywidualnej kolejnych struktur formalnych logiki moralnej a także wskazuje na stale powiększające się pole etycznych kompetencji, czyli na coraz sprawniejsze sumienie. Każde stadium operuje coraz bardziej złożonym w stosunku do poprzedniego schematem argumentacji, operacje są coraz bardziej ogólne i abstrakcyjne, coraz lepiej utrwala się poczucie tożsamości moralnej indywiduum, struktura myślenia staje się coraz bardziej stabilna, jednocześnie dając coraz więcej możliwości rozstrzygania problemów moralnych (i dla większej zbiorowości ludzkiej) niż struktura poprzednia. U Kohlberga stadium doskonałe to wybór wartości najwyższych, obiektywnie ważnych. Habermas modyfikuje tę teorię, stwierdzając, że na ostatnim stadium rozwoju podmiot wybiera wartości obiektywne społecznie ${ }^{53}$. W konsekwencji prawda o dobru moralnym jest, zgodnie $\mathrm{z}$ tą teorią, efektem porozumienia ${ }^{54}$.

Według Habermasa, w moralności możemy zaobserwować rozwój argumentacji - od perspektywy indywiduum (stadium najwcześniejsze), czyli perspektywy subiektywnej, do perspektywy uniwersalistycznej i w tym sen-

49 J. Habermas, Teoria, t. 1, s. 462.

${ }^{50}$ Zob. J. Górnicka-Kalinowska, dz. cyt., s. 117; A. Szahaj, dz. cyt., s. 93-95.

${ }^{51}$ Zob. J. Górnicka-Kalinowska, dz. cyt., s. 116-117, 123.

${ }^{52}$ Zob. J. Habermas, Teoria, t. 1, s. 132-135; L. Kohlberg, R. Mayer, Rozwój jako cel wychowania, w: Z. Kwieciński, L. Witkowski (red.), Spory o edukacje. Dylematy i kontrowersje we wspótczesnych pedagogiach, Warszawa 1993, s. 56.

${ }^{53}$ Zob. J. Górnicka-Kalinowska, dz. cyt., s. 124-125.

${ }^{54}$ Zob. A. Szahaj, dz. cyt., s. 92. Habermas definiuje praktykę komunikacyjną jako praktykę, „która, mając za podłoże i tło świat życia, jest nastawiona na osiąganie, utrzymywanie i odnawianie konsensu, $i$ to konsensu, który opiera się na intersubiektywnym uznawaniu poddawanych krytyce roszczeń ważnościowych”. J. Habermas, Teoria, t. 1, s. 45, 49. 
sie «obiektywnej» $\aleph^{55}$. Stadium przedkonwencjonalne charakteryzuje perspektywa utylitarna, stadium konwencji - konflikt postaw utylitarnych i postaw komunikacyjnych podporządkowanych normom moralnym, wreszcie stadium autonomiczne jest wolnym dialogiem wielu podmiotów. Jest to stadium wyboru norm powszechnych i bezstronnych; jeśli wybór ten ma doprowadzić do nowego ładu społecznego, musi być on poprzedzony procedurą dys$\mathrm{kusji}^{56}$. Proces dojrzewania sumienia to proces wczuwania się w cudzą rolę, czyli rozwój społecznego punktu widzenia ${ }^{57}$. Poziom pierwotny to wymiana świadczeń (poziom wzajemności). Wczucie się w sytuację innego łączy się z utratą własnej perspektywy. Na poziomie wyższym rozwija się świadomość autorefleksyjna. Nadawca i odbiorca wchodzą w sytuację innego, nie tracąc własnej perspektywy. Na kolejnym poziomie dołączana jest perspektywa anonimowego obserwatora, co w ostateczności prowadzi do odkrycia bezosobowej normy moralnej. O ile zasadą stadium przedkonwencjonalnego była wzajemność (wymiana świadczeń), zaś stadium konwencji charakteryzował punkt widzenia idealnego obserwatora - co w jakiejś mierze «obiektywizowało» słuszność wyboru - o tyle w stadium ostatnim, najwyższym, osią myślenia moralnego jest, zdaniem Habermasa, dyskusja różnych perspektyw moralnych w celu wykrycia moralnej «prawdziwości». Jest to stadium poszukiwania kryterium ważności norm, stadium procedury. Nie wystarczy, by norma była umowna - musi być ona w jakimś sensie «prawdziwa». Umowny może być ład społeczny, umowny jest status instytucji, ale norma działania musi mieć charakter moralny ${ }^{58}$.

${ }^{55}$ Zob. J. Habermas, Teoria, t. 1, s. 132-135; J. Górnicka-Kalinowska, dz. cyt., s. 128.

${ }^{56}$ Zob. J. Górnicka-Kalinowska, dz. cyt., s. 129.

57 Zob. J. Habermas, Wierzyć i wiedzieć, „Znak” 9 (2002), s. 10-18.

${ }^{58}$ Zob. J. Górnicka-Kalinowska, dz. cyt., s. 130-131. W obszarze praktycznomoralnym racjonalną Habermas nazywa taką osobę, „która swe działania może uprawomocnić przez odwołanie się do istniejących kontekstów normatywnych. W szczególności zaś odnosi się to do takiej osoby, która w wypadku normatywnego konfliktu związanego z działaniem postępuje w sposób rozsądny [...], czyli ani nie ulega afektom, ani też nie kieruje się bezpośrednim interesem, lecz stara się bezstronnie ocenić spór z moralnego punktu widzenia oraz zaradzić mu w trybie konsensualnym. Medium, za pośrednictwem którego poddać można hipotetycznemu sprawdzeniu to, czy norma kierująca działaniem - niezależnie od tego, czy jest ona faktycznie uznawana czy też nie - może czy też nie może zostać uprawomocniona, jest dyskurs praktyczny, czyli ta forma wymiany argumentów, w ramach której tematem stają się roszczenia do słuszności normatywnej”. J. Habermas, Teoria, t. 1, s. 48. 


\section{Konsekwencje przyjęcia poszczególnych kategorii}

Aby odpowiedzieć na pytanie sformułowane w tytule artykułu, spróbujmy teraz porównać koncepcję rozwoju moralnego poprzez rozwój cnót moralnych z koncepcją rozwoju moralnego odwołującą się do kategorii kompetencji moralnych.

\subsection{Absolutny czy relatywny porządek moralny?}

Trudności z określeniem tego, co jest dobre a co złe w sferze moralności, rozbieżność zdań w tej dziedzinie, jak również błędy, które pojawiają się w ocenach dobra i zła, skłaniają wiele osób do opowiedzenia się za relatywnym porządkiem moralnym. Stwierdza to również Arystoteles w Etyce nikomachejskiej, gdy mówi: ,Tak też co do pojęć piękna moralnego i sprawiedliwości [...] panuje tak daleko idąca rozbieżność i niestałość zdań, że pojawił się nawet pogląd, iż istnienie swe zawdzięczają one tylko umowie, a nie przyrodzie rzeczy" ${ }^{59}$. Nietrudno jednak zauważyć, że sam Arystoteles wyraża przekonanie, iż dobro i zło zależą od „,przyrody rzeczy” - dziś użylibyśmy sformułowania „natura rzeczywistości”, które implikuje także ,prawo naturalne". Rozpoczynająca się od Arystotelesa tradycja refleksji nad cnotą budowana jest więc na założeniu absolutnego porządku moralnego, zakorzenionego w rzeczywistości. Nie jest to, oczywiście, równoznaczne ze stwierdzeniem, że ów porządek jest doskonale odkrywany i opisywany przez człowieka. Wręcz przeciwnie, człowiek nie tylko popełnia błędy w ocenie rzeczywistości, często nie dostrzega lub nie uwzględnia wielu danych z niej płynących, a ponadto nieustannie staje wobec konieczności rozstrzygania dylematów, które związane są z rozwojem cywilizacyjnym i nigdy wcześniej nie pojawiły się.

Teoria Habermasa - według deklaracji Autora - również nie powinna prowadzić do relatywizmu. Wręcz przeciwnie, ma służyć przezwyciężeniu permisywizmu, naznaczającego współczesne życie społeczne ${ }^{60}$. Formułowanie normy na drodze działania komunikacyjnego przypomina odkrywanie prawdy zgodnie z założeniami hermeneutyki. Zrozumienie i uwzględnienie roszczeń ważnościowych innych osób, a tym samym ogląd sytuacji z innych niż własna perspektyw, ma bowiem przyczyniać się do doskonalszej

\footnotetext{
59 Arystoteles, dz. cyt., 1094b.

${ }^{60}$ Zob. J. Górnicka-Kalinowska, dz. cyt., s. 122.
} 
odpowiedzi na pytanie o moralność i prawomocność działania w określonych sytuacjach. Można by nawet powiedzieć, że teoria cnót i teoria kompetencji nie pozostają ze sobą w sprzeczności. Gdy jednak przyjrzymy się dokładniej koncepcji Habermasa, musimy zwrócić uwagę, jak opisuje on świat społeczny. To nie on jest źródłem norm, które rozum powinien odkrywać i definiować, ale odwrotnie - zadaniem rozumu jest nadawanie znaczeń, wartościowanie i emancypacja z zastanych struktur. Formułowanie norm na drodze uwzględniania roszczeń ważnościowych innych osób jest więc $\mathrm{w}$ gruncie rzeczy formą międzyludzkiego, zawartego w danym momencie, porozumienia. Świat społeczny ma być bowiem zależny od człowieka. Być może wnioski, które wyciągam, są zbyt daleko posunięte, ale moim zdaniem teoria Habermasa umożliwia relatywizację dobra i zła ${ }^{61}$.

\subsection{Czym jest sankcja?}

Różnicująca koncepcję cnoty oraz koncepcję kompetencji jest kwestia sankcji. Teoria cnót wskazuje na sankcję, którą jest osiągnięcie lub nieosiągnięcie szczęścia. Mówi, że - chcąc osiągnąć szczęście - człowiek musi liczyć się z rzeczywistością. Działanie niegodziwe będzie zatem łączyło się zawsze z nieosiągnięciem szczęścia. W teorii kompetencji moralnych nie pojawia się natomiast zupełnie kategoria sankcji. Wytłumaczeniem jest relatywizacja dobra i zła moralnego. Dokonywane przez człowieka wartościowanie i nadawanie znaczeń implikuje zależność wartości i norm moralnych od samego człowieka, a konkretniej od jego rozumu. Byłoby więc sprzecznością, gdyby równocześnie zakładać pochodzenie normy od rozumu i zawarty w niej błąd. Warto jednak w tym kontekście zadać pytanie, jak wytłumaczyć sytuację, w której człowiek - działając w przekonaniu, że czyni dobrze nabiera w trakcie czynu albo osądu po czynie przekonania, że był w błędzie i powinien był postąpić zupełnie inaczej. To zjawisko może być wytłumaczone jedynie wówczas, gdy założymy inne niż od rozumu pochodzenie norm moralnych - inne, czyli pochodzenie z rzeczywistości przedmiotowej. Konsekwentnie także tylko wówczas, gdy to rzeczywistość implikuje dobro i zło moralne, możemy mówić o sankcji.

${ }^{61}$ Na marginesie można zadać pytanie, czy zbudowanie normy na drodze porozumienia jest w praktyce możliwe? Jak chociażby uzgodnić roszczenie ważnościowe - niewyrażone poczętego dziecka, które z pewnością uznałoby za ważne swoje prawo do życia, oraz roszczenie ważnościowe matki, która „nie czuje się jeszcze gotowa do macierzyństwa”. A może ustalanie norm na drodze komunikacji dotyczy tylko tych, którzy mogą w owej komunikacji uczestniczyć? 


\subsection{Na czym polega rozumność i wolność dzialań?}

Jednym ze źródeł rozwoju teorii kompetencji społecznych i moralnych była alienacja człowieka, polegająca na praktycznym zakwestionowaniu jego podmiotowości w życiu społecznym, gospodarczo-ekonomicznym, w kulturze. Można by zapytać, czy teoria cnót z jej założeniem istnienia obiektywnego porządku moralnego nie przyczyniają się do alienacji człowieka, polegającej na odebraniu jego rozumowi prawa do wartościowania i nadawania znaczeń. Czy teoria ta nie zaprzecza wolności i podmiotowości człowieka. W odpowiedzi należałoby odwołać się do tego, na czym polega wolność i podmiotowość w myśli arystotelesowsko-tomistycznej. Po pierwsze, teoria ta mimo założenia istnienia obiektywnego porządku moralnego nie głosi doskonałego poznania dobra i zła, co więcej konkretne dylematy moralne rodzą się w niepowtarzalnych sytuacjach i w nieustannie zmieniających się okolicznościach, co wymaga od rozumu aktywności, polegającej na odnalezieniu właściwego sposobu postępowania w tej sytuacji, w jakiej znalazł się człowiek. Po drugie, wolność jest rozumiana jako zdolność wyboru tego, co rozum określił jako dobro. Kardynalne cnoty moralne, doskonalące wolę i władze zmysłowe, są bowiem rozumiane jako predyspozycje do dochowania wierności rozumowi. Czym jest zatem brak cnoty? Brakiem wolności, brakiem podmiotowości, brakiem wewnętrznej integracji. O braku cnoty możemy mówić wówczas, gdy wola nie jest zdolna do realizacji dobra odkrytego przez rozum - a ma to miejsce wówczas, gdy na decyzję wpływają uczucia, na przykład lęk albo pożądanie jakiegoś dobra zmysłowego, które odciąga od dobra duchowego ${ }^{62}$. Idąc tropem refleksji arystotelesowsko-tomistycznej, można powiedzieć, że sprowadzając rolę rozumu praktycznego do funkcji poznawczych nie kwestionuje się rozumności i wolności człowieka, czyli jego podmiotowości. Równocześnie, przypisanie rozumowi funkcji wartościujących i znaczeniotwórczych, co ma miejsce w teorii Habermasa, nie jawi się jednoznacznie jako obrona podmiotowości człowieka. Roszczenia ważnościowe mogą być wszak wysuwane nie pod wpływem rozumnego oglądu rzeczywistości, ale pod wpływem nastawionych na dobra zmysłowe uczuć. Niedostrzegając ograniczeń i zagrożeń, z jakimi związana jest działalność rozumu, można w gruncie rzeczy wypaczyć jego działalność.

${ }^{62}$ Zob. J. Horowski, Koncepcja integralnego, cielesno-duchowego rozwoju człowieka w ujęciu pedagogiki tomistycznej, w: P. Błajet (red.), Ciało - edukacja - umyst, Bydgoszcz 2010, s. 43-59; tenże, Podmiotowość w pedagogice chrześcijańskiej o inspiracji tomistycznej, „Paedagogia Christiana” 2/24 (2009), s. 63-78. 


\subsection{Jak wspierać rozwój moralny w wychowaniu?}

Różnice między koncepcją cnót oraz koncepcją kompetencji pojawiają się również w kwestii wychowania moralnego. Ponieważ - jak stwierdził już Arystoteles - człowiek w swoim działaniu dąży do szczęścia, a szczęście osiągane jest wówczas, gdy realizuje on określone dobra, dlatego w tradycji arystotelesowsko-tomistycznej wychowanie moralne związane jest nie tyle z nauczaniem, przekazywaniem norm, ale umożliwieniem doświadczenia dobra, które będzie pociągało - doświadczenie da wychowankowi pewność, że realizacja tego konkretnego dobra przyniesie mu szczęście. Doświadczenie określonego dobra $\mathrm{w}$ ramach wychowania kształtuje bowiem nie tylko rozum, któremu dostarcza informacji o podmiocie oraz otaczającej go rzeczywistości, ale także wolę, której pokazuje, z którym czynem związane jest zadowolenie, oraz uczucia, które mogą być modyfikowane na skutek doświadczenia (na przykład człowiek może przełamać lęk, który towarzyszył myśli o podjęciu określonego działania).

Kształtowanie kompetencji moralnych łączy się w kwestii wychowania z oddziaływaniem wyłącznie na rozum. Rozwój ma dokonywać się poprzez dostrzeżenie perspektywy innego człowieka, którego dany czyn dotyczy. W tym kontekście rodzi się jednak pytanie, czy wychowanek będzie potrafił przełamać lęk w sytuacji, gdy czyn postrzegany jako dobry będzie czynem niebezpiecznym, albo czy będzie potrafił poświęcić jakieś dobro osobiste dla osiągnięcia dobra, które będzie postrzegane jako obiektywnie wyższe? Arystoteles dosyć dosadnie wypowiedział się na temat takiej edukacji moralnej, która nie łączy się z czynem:

Ludzie jednak na ogół nie postępują w ten sposób, lecz, uciekając się do rozważań słownych, sądzą, że uprawiają filozofię i że dzięki temu osiągną wysoki poziom etyczny; zachowują się przy tym podobnie jak chorzy, którzy uważnie słuchają, co mówi lekarz, nie spełniają jednak żadnego z jego zaleceń. Tak samo więc jak tamci, lecząc się w ten sposób, nie uzyskają zdrowia cielesnego, tak samo i ci, filozofując w ten sposób, nie nabędą zalet duchowych ${ }^{63}$.

\section{Podsumowanie}

Prowadzone powyżej rozważania uzmysławiają, że wprowadzenie do współczesnych dyskusji o wychowaniu moralnym kategorii kompetencji

${ }^{63}$ Arystoteles, dz. cyt., 1105 b. 
związane jest z szerszymi przemianami w myśleniu o człowieku, życiu społecznym, ludzkim poznaniu oraz moralności. Teoria kompetencji moralnych oparta jest bowiem na zupełnie innych założeniach niż teoria cnót moralnych. W podsumowaniu wróćmy więc do pytania zawartego w tytule: sprawności czy kompetencje moralne? Kompetencje moralne posiadają charakter intelektualny, a jakość moralna czynu konkretnego człowieka nie jest pochodną wyłącznie intelektualnego oglądu rzeczywistości, do której czyn się odnosi. Odwołanie się w wychowaniu wyłącznie do kategorii kompetencji może zatem skutkować dojrzewaniem ludzi, którzy będą potrafili dostrzegać perspektywę innego człowieka, będą potrafili negocjować normy moralne, ale gdy staną w sytuacji wymagającej od nich męstwa w realizacji dobra, będą wycofywać się. Powyższe stwierdzenie nie oznacza jednak negacji wartości kompetencji moralnych. Fundamentem cnoty jest bowiem rozumienie rzeczywistości - bez roztropności inne cnoty nie są w stanie funkcjonować, a warunkiem roztropności jest zrozumienie przez podmiot otaczającego go świata. Ważne jest zatem, aby dojrzewający człowiek uczył się patrzeć na ów świat z wielu perspektyw, poszukując odpowiedzi na pytanie, na czym polega dobro. Porównanie teorii kompetencji moralnych z teorią cnót moralnych pozwala jednak, w mojej opinii, na zgłaszanie wątpliwości, czy sprawności moralne można zastąpić kompetencjami czy to prowadząc refleksję nad wychowaniem moralnym, czy też podejmując próbę wspierania dojrzewającego człowieka w jego rozwoju moralnym. Czy zatem próba zbudowania teorii moralności i moralnego rozwoju na fundamencie teorii, która jest teorią budowania społecznego porozumienia, nie jest próbą zbudowania spójnego systemu praktyki komunikacyjnej i wychowawczej kosztem nieadekwatnej teorii moralności i moralnego rozwoju?

\section{Moral Efficiency or Moral Competency? (Summary)}

The question about the concept of moral education is one of the most important questions within the discipline of pedagogy. There are numerous answers that vary depending on the cultural context as well as anthropological, epistemological or ethical assumptions dominant within it. As a response to this issue, ancient thinkers developed the theory of moral virtues, which are the culmination of moral education and whose development is included in the teleology of education. A concept of the development of virtues was formulated, for instance, by Aristotle. It was then creatively advanced by Thomas Aquinas, and these days Alasdair MacIntyre and neo-Thomists refer to it. However, in today's discussions about moral education it is the category of moral competence that is more often mentioned and it is based 
mainly on the theory of communicative action by Jürgen Habermas. This category appears, for instance, in the official documents that describe the effects of education. The author of this article raises a question of whether moral education can be reduced to the development of moral competency. In an attempt to answer this question, the author describes characteristic features of both categories and then analyses pros and cons of various solutions. 